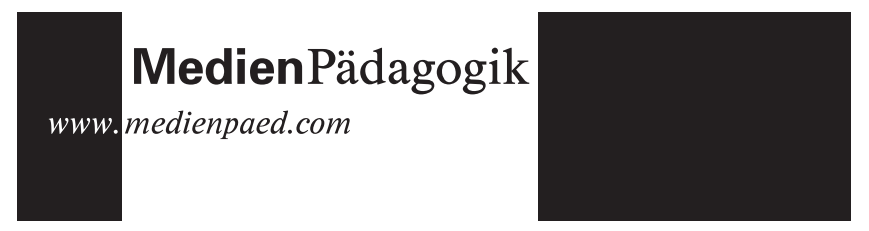

María Luisa Sevillano García

9.4.2001

Reasons and Objectives Integrating Press into the Curriculum: An Empirical Study

Our study is partly based on the UNESCO' General Assemblies Recommendations, and its guidelines considered by many countries. Moreover, is based on the current legal Spanish regulations of the Ministry of Education and Culture relating the curricular integration of the communication media into teaching. The law does not ensure the results expected right away, but provides guidelines and stimulus to start the process with some guarantees. On the other hand, our study wants to answer to the new situation created by the massive expansion of communication media and new technologies, and also their uncontrolled effects and the necessity of relating teaching with the new realities.

Motivation, didactic possibilities, relationship with the press among others is present when teachers start working with press, showing similar scores. More that half of teachers finds these new resources as feelings enhancers, what is new and very valuable. If this is true, we will be in front of a more humanist and humanizing model. Training of the global man is important, not only reasoning but also feelings. There is also post experiment evidence that press generates a creative attitude in students, and at the same time it provides them with new knowledge, which is very important.

Because of these and other reasons there must be training for a new type of teacher that integrates media to attain new learning and new attitudes towards media and new knowledge without forgetting a critical and analytical attitude to design a new model of student.

\section{Theoretical bases}

New technologies and communication media, especially their contents and effects have been universalised in time and space. They reach every field and cover a great deal of any type of manifestation. They are not created to be locked up in the classrooms, to wait in safe laboratories. Teachers and students are in a similar position facing this phenomenon whose importance is not very considered. Students and teachers get together to profit from this new resources and allies that are before, during and after our tasks of teaching and learning

It is necessary to be able to live with them. Therefore, we think new teachers need an especial sensitivity to get in touch, to use these new communication media. New technologies and their messages are not limited to a single subject or level. They can go through the whole educative system and they surpass it in time and space. We are facing the global school. Mi thought starts then, considering these new universal and powerful resources which break the conception of specialist teacher who masters certain questions of a subject, i.e. physics labs, chemistry, natural sciences, physical education, etc, where the teacher who does not teach these subject does not need to be a good teacher to work with his/her subject.

The UNESCO, long time ago started to give in its General Assemblies recommendations to improve the educational policies of its members, referring the integration of Mass Media and New Technologies in Teaching and Education. We can notice a progressive and homogenous evolution towards this integration. I mention some of them:

\begin{tabular}{|l|l|}
\hline $\begin{array}{l}\text { 1949 } \\
\text { th }\end{array}$ & $\begin{array}{l}\text { The General Manager will promote the distribution and } \\
\text { storing of books and newspapers, as well as radio } \\
\text { equipments and projection machines to develop the use of } \\
\text { cinema and radio with educative aims. }\end{array}$ \\
\hline $\begin{array}{l}\text { 1950 } \\
\text { Florence }\end{array}$ & $\begin{array}{l}\text { Preparation and use of audiovisual material, radio, press } \\
\text { cinema and radio for education will be boosted. }\end{array}$ \\
\hline $\begin{array}{l}\text { 855 } \\
\text { Monte- } \\
\text { video }\end{array}$ & $\begin{array}{l}\text { The General Conference, aware of the importance of media } \\
\text { in the last years, invites the General Manager to promote the } \\
\text { access to media and make easier the free flow of } \\
\text { information. It also pretends to promote the creation and } \\
\text { dissemination of programs with cultural, scientific or } \\
\text { educative contents. }\end{array}$ \\
\hline 1960 & \begin{tabular}{l} 
Educative, scientific and cultural audiovisual media are very \\
\hline
\end{tabular} \\
\hline
\end{tabular}


11th $\quad$ important for UNESCO. These media are important and Paris unique instruments for adult people education of all ages, especially in basic and adult education schools.

1962 1. The General Conference invites the General Manager to

12th collaborate in the promotions of audiovisual services for

Paris educations, especially adult people's education.

2. The General Manager supports the experimental programs and pilot projects regarding teaching with audiovisual media

1964 The General Manager is asked to help radio, television,

13th

Paris cinema and audiovisual media organizations to produce radio

1966 programs and television films, photographs, films and other visual materials for education, science and culture

The General Conference proposes the General Manager to

14th promote the use of new methods and techniques in school

Paris education, high school and extra-curricular teaching especially computer assisted learning and other media based on radio, cinema and television.

1970 The General Conference, aware of the important role which

16th play media to make people literate, invites the General

Paris Manager to boost the use of radio and television in non formal education, in order to satisfy the needs of those who due to economic or labour reasons have to be away from school for a long time.

1976 The General Conference recognises the dynamic role of 19th media and their contribution to the cause of literacy and Nairobi education, so it invites the General Manager to promote the creation of programs and audiovisual material for education, culture and science, facilitating at the same time their national and international diffusion

1978 The General Conference aware of the importance of media

20th to countries development, invites the General Manager to

Paris prepare new pilot projects related to the media, and help local communication media to prepare radio programs about development and teaching for the first childhood.

1980 The General Conference in the program «The

21st communication serving Mankind» suggests the General Belgrade Manager to reinforce the International Net of the
Communication research and policy Documentation Centre.

1. Contribute to an action plan to reinforce the contribution of media in the process of literacy improvement.

2. Improve media related education, insisting on the development of a critical spirit, the capacity to react in front of any form of information and the education of users to defend their rights.

1983 The General Conference aware of the important role of new 22nd technologies in the development of society asks the General Paris Manager to promote research about the adequacy of educative contents for the needs of society and the influence of media in children's education.

1985 1. The General Conference considers that using new 23rd electronic technologies is more and more an essential aspect Sofia in education, as a tool for students and teachers, as well as important subject to consider in the school syllabus planning. 2. Because of these reasons it asks the General Manager to improve the access to information: new technologies, normalization and intercommunion of information systems, and to offer the educative institutions help to choose and apply logical and adequate supports.

1989 The General Conference, considering the use of new technologies of information, in a larger frame of methods and technologies of education conforms a very important aspect of the education of the member states, as they are instruments for teachers and students, tools of training, important area of educative research for educative innovation, research and development, theme of the syllabus of study and means of management of the formal and non formal systems of education and of the process of teaching and learning looking forward to improving quality, and external an internal efficiency:

1. The General Manager is asked to promote the use of new technologies of information and communication in Education (Effects on structures, organization, contents and methods of education systems.). Information y communication en la education (Effects on the structures).

2. To promote extracurricular activities for teaching 
3. Considering the possibilities offered by new technologies of information and communication and their influence on the educative process and the functioning of the education systems, the General Conference asks to promote and intensify methodological, pedagogical and didactic research necessary for both teachers and students to master the new information technologies and to know their implications on the educative system.

4. The priority for this decade is investment in culture and education, in technology and communication media, the promotion of cultural and educative dimension in the programs of electronic communication media, collecting and disseminating studies about new trends of information and communication.

5. Support the development and establishment of information nets in schools and libraries and make the access to them easier.

6. The influence of media in the socialization of children and youngsters is more and more noticed. Therefore, it is necessary to train teachers and prepare students to analyse and use media. On the other hand media should be asked to promote and cooperate with the educative sector on training and teaching.

7. The General Conference outstands the potential of new technologies to develop teaching methods and information flow development

\section{Spanish Regulations}

There are legal texts, which are similar as they draw action frames leading to teaching quality improvement on the basis of the new training of teachers and the omnipresence of media and new technologies. That means to provide teaching institutions with means and resources but it is not sufficient. I sum up some of the last documents which are quite significant in the sense that teachers can know when he/she is working in an autonomous way is following the law with a great responsibility, in contrast with other institutions which do not respect it. 
structure transformation. This teaching and learning has the goal of

Educative Research and Teachers' Training Plan from 1989

This plan starts from some clear principles. These are briefly:

1. Technologies have an essential role in transforming society.

2. Education should be in charge of comprehension of the outer world.

This would be impossible without technologies.

3. An almost permanent professional re-adaptation will be necessary.

Without technologies this attitude and reality would not be possible.

4. All new educative systems share the interest in integrating technologies, whose cooperation is necessary to innovate.

Is therefore urgent to design an action plan, which allows accomplishing the following goals among others:

1. Teachers' training so that teachers are qualified to integrate new technologies into the curriculum.

2. Guarantee that teachers really integrate new technologies of information into teaching.

3. To make easy for teachers to acquire the theoretical bases and operative skills in the application of the didactic means based on new technologies.

4. To qualify teachers to be able to think about their own practice based on new technologies.

With these premises the Act of the Curricula in 1991 was elaborated, with concepts and procedures very concrete about integration of new technologies in infant, primary and secondary school levels. There were also some indications on students' attitudes to attain. I will only mention some of them:

\section{General Principies}

The social need of training critical and receptive people, able to structure media and new technologies messages, is written as an objective in the Primary and Secondary Education Curriculum. In this way, together with the improvement of communicative capacities, we try to give the students analysis instruments to ensure a better capacity of judgement and personal assessment of messages.

The presence of information and communication technologies in the classroom is due to two reasons. On the one hand, these technologies provide with new ways of communicating at school, improving the existing ones. On the other hand they impulse schools to go towards society whish should consider them as one of the factors of social contributing to develop in students the following capacities:

Know and analyse the current society communication processes, reflecting about its linguistic sociological, psychological, technological, economic, ideological politic dimensions.

Understand how information and communication technologies work, keeping reflective and critical attitudes.

Use information and communication technologies to produce messages, which integrate different languages.

Value the personal experience in production and emission of messages.

Value personal experience in production and emission of messages.

Counsel the expressive and entertaining capacities of students towards own and autonomous audiovisual treatments that surpass the imitation of established models.

Analyse and value the unfair uses of technologies noticing their ideological contents.

Interpret the content and the intention of messages produced through information technologies decoding its formal and structural elements.

\section{Concepts}

Local sources, news agencies, information on magnetic support, information on optical support, CD- ROM data bases managers, telex, videotext, remote and telemetric sources

Information choice

Information reception

Receptor training (knowledge of the different codes)

Journal, television radio registers.

Nets and information and communication nets. Power concentration, cultural uniformity and informative pluralism. Advertisement and consumers habits

Critical attitude towards information received through the different media.

Sensitivity facing the influence media has on opinion forming, paying especial attention to advertisement, the sexist and racist stereotypes, and consume.

Communication media. Different media and their utility as leisure instruments and communicators of social events.

The most popular representation media: cinema, video, television, and 
computers

Mass media:

Press, radio, television, cinema, video, satellites

Information, news and advertisement, consumer's habits.

Information through image: computers.

Interpersonal communication media

Computer science: storage, treatment and dissemination of information.

\section{Procedures}

Search, selection and register of information relating current questions using media.

Comparative analysis and critical assessment of information provided by mass media (radio, press, television) on the same facts or question. Identify and analyse the essential elements (sender, receptor, channel, etc.) related with any media communication act.

Access and consult of different information sources where technological resources intervene (data bases, image banks, sound files).

Choice, organization and treatment of information to make different messages.

Strategies to select and classify information (interrogation of a data base, preparation of an inquiry I a data bank of telemetric access, etc.). Understanding of messages taken from the national and foreign information sources (press radio, television, advertisement, etc).

Analysis of the interrelation and functioning of messages (decoding of the message, perception recognition, iconic, iconographic codes as taste and sensibility ones, rhetoric, stylistic, etc.).

Search of relevant hints to build up messages that show the communicative intentions of the sender.

Observation and exploration of the mechanisms evident or hidden used in media to induce to specific interpretation of messages.

Use of technological ways to produce, present ideas, compositions, electronic paging, printing, editing, and disseminating information.

Use of tools and machines: photo cameras, videos, computers.

To look up the communication processes, using audiovisual and computer technologies in an integral way, outlining their importance in the different communication stages.
To be especially centred in the processes of audiovisual communication, using specifically audiovisual technologies.

To lead the way about the communication processes from the perspectives of technology of information and telematics.

To focus the activity in mass media (press, radio, television).

\section{Attitudes}

Right assessment of the utility of image (television, cinema, etc.).

Understand the possibilities of sound, image, as representation elements and use them to express ideas, feelings and living experiences in a personal and autonomous way in situations of play and communications.

Know media, which operate with sounds and image and the contexts that develop, being able to appreciate the elements with an expressive and aesthetic interest.

All this on the bases of a new sensibility and training of teachers.

\section{Research Findings}

In the last 15 years the scientific community in mass media, new technologies and education has been able to structure a series of congresses, conferences, meetings, publications and research more or less periodical which allow us to notice the great awareness produced all over the world about these subjects relating communication and teaching. (Bartolomé Crespo, 1991 and 1996, Zamora; De Pablos Sevilla 1994 and 1996; Aguaded, Huelva 1991; Rodriguez Orellana 1994 and ss., among others).

In the field of media didactics there are specific strategies and the reconversion to other more traditional ones. There is also a noticeable contributions of each of them in such a way that teachers can go to action and use this research applied (Gallego Arrufat, 1997, Sevillano y Bartolomé 1997, Aguaded, 1997). The field of the effects of use of media has been analized sometimes, obtaining safe and optimal results. The book Desarrollo de la inteligencia mediante la integración curricular de la prensa, (Developing intelligence thanks to a curricular integration of Press) collected the results of an investigation carried out in Zamora during four years with a sample of 10 groups of students, five experimental and five of control. It presents well-contrasted data about the subject. 
As I cannot summarize the results of all researches done in the field of technologies and media as an example I present some global results of researches I have carried out lately. Participant teachers were initially trained in technologies and media. The different tables give a context to the origin and extension of the research done.

\section{Results of the Research}

\section{The Sample}

\begin{tabular}{|l|c|c|}
\hline \multicolumn{3}{|c|}{ 1. Sample classification: sex } \\
\hline Women & 281 & 85.4 \\
\hline Men & 45 & 13.7 \\
\hline No answer & 9 & 0.9 \\
\hline TOTAL & 329 & 100.0 \\
\hline
\end{tabular}

\begin{tabular}{|l|c|c|}
\hline \multicolumn{3}{|c|}{ 2. Work place educative level } \\
\hline Nursery & 69 & 21.0 \\
\hline Primary & 155 & 47.1 \\
\hline Secondary & 40 & 12.2 \\
\hline Vocational Training & 15 & 4.6 \\
\hline Bachillerato & 18 & 5.5 \\
\hline Adults & 3 & 0.9 \\
\hline University & 2 & 0.6 \\
\hline Others & 11 & 3.3 \\
\hline Languages & 2 & 0.6 \\
\hline No answer & 14 & 4.3 \\
\hline Total & 329 & 100.0 \\
\hline
\end{tabular}

\begin{tabular}{|l|c|c|}
\hline \multicolumn{3}{|c|}{ 3. Research was carried out in a context } \\
\hline Urban & 183 & 55.6 \\
\hline Rural & 115 & 35.0 \\
\hline No answer & 31 & 9.4 \\
\hline
\end{tabular}

4. Teachers worked on these subject areas:

$11 / 20$

\begin{tabular}{|l|c|c|}
\hline All & 153 & 46.5 \\
\hline Social Sciences & 37 & 11.2 \\
\hline Natural Sciences & 36 & 10.9 \\
\hline Language and Literature & 20 & 6.1 \\
\hline Languages & 16 & 4.9 \\
\hline Mathematics & 12 & 3.6 \\
\hline Fine Arts & 3 & 0.9 \\
\hline Religion & 3 & 0.9 \\
\hline Hotel industry studies & 1 & 0.3 \\
\hline Technology & 1 & 0.3 \\
\hline Sport Education & 1 & 0.3 \\
\hline Physics & 1 & 0.3 \\
\hline $\begin{array}{l}\text { Others and no answer/does not } \\
\text { know }\end{array}$ & 3411 & 10.33 .3 \\
\hline
\end{tabular}

\begin{tabular}{|l|c|c|c|c|c|c|}
\hline \multicolumn{7}{|c|}{ 5. Media used in the study } \\
\hline & Newspapers & \multicolumn{2}{c|}{ Videos } & \multicolumn{2}{c|}{ Television } \\
\hline Never & 33 & 10.0 & 147 & 44.7 & 149 & 45.3 \\
\hline Almost Never & 51 & 15.5 & 107 & 32.5 & 118 & 35.9 \\
\hline Some times & 136 & 41.3 & 34 & 10.3 & 36 & 10.9 \\
\hline Quite often & 75 & 22.8 & 26 & 7.9 & 9 & 2.7 \\
\hline Always & 21 & 6.4 & 3 & 0.9 & 2 & 0.6 \\
\hline No answer & 13 & 4.0 & 12 & 3.6 & 15 & 4.6 \\
\hline & \multicolumn{2}{|c|}{ Radio } & Computers & Magazines \\
\hline Never & 209 & 63.5 & 72 & 21.9 & 48 & 14.6 \\
\hline Almost never & 84 & 25.5 & 107 & 32.5 & 104 & 31.6 \\
\hline Some times & 16 & 4.9 & 92 & 28.0 & 131 & 39.8 \\
\hline Quite often & 6 & 1.8 & 35 & 10.6 & 32 & 9.7 \\
\hline Always & 1 & 0.3 & 8 & 2.4 & 2 & 0.6 \\
\hline No answer & 13 & 4.0 & 15 & 4.6 & 12 & 3.6 \\
\hline
\end{tabular}

\begin{tabular}{|l|c|c|c|c|c|c|}
\hline \multicolumn{6}{|c|}{ 6. Pedagogic results obtained with the media studied } \\
\hline & \multicolumn{2}{|c|}{ Newspapers } & \multicolumn{2}{c|}{ Videos } & \multicolumn{2}{c|}{ Television } \\
\hline Poor & 24 & 7.3 & 49 & 14.9 & 102 & 30.7 \\
\hline Sufficient & 22 & 6.7 & 132 & 40.1 & 132 & 40.1 \\
\hline Satisfactory & 67 & 20.4 & 75 & 22.8 & 34 & 10.3 \\
\hline
\end{tabular}




\section{MedienPädagogik}

\begin{tabular}{|l|c|c|c|c|c|c|}
\hline Good & 150 & 45.6 & 43 & 13.1 & 29 & 8.8 \\
\hline Very good & 49 & 14.9 & 9 & 2.7 & 7 & 2.1 \\
\hline No answer & 17 & 5.2 & 21 & 6.4 & 26 & 7.9 \\
\hline & \multicolumn{2}{|c|}{ Radio } & \multicolumn{2}{c|}{ Computers } & \multicolumn{2}{c|}{ Magazines } \\
\hline Never & 209 & 63.5 & 72 & 21.9 & 48 & 14.6 \\
\hline Almost never & 84 & 25.5 & 107 & 32.5 & 104 & 31.6 \\
\hline Some times & 16 & 4.9 & 92 & 28.0 & 131 & 39.8 \\
\hline Quite often & 6 & 1.8 & 35 & 10.6 & 32 & 9.7 \\
\hline Always & 1 & 0.3 & 8 & 2.4 & 2 & 0.6 \\
\hline No answer & 13 & 4.0 & 15 & 4.6 & 12 & 3.6 \\
\hline
\end{tabular}

7. Strategies developed and applied working in teams with press and technologies

\begin{tabular}{|l|c|c|}
\hline Role playing & 193 & 58.7 \\
\hline Data collection & 183 & 55.6 \\
\hline Games & 173 & 52.6 \\
\hline Research & 162 & 49.2 \\
\hline Animation techniques & 153 & 46.5 \\
\hline Publishing techniques & 133 & 40.10 \\
\hline Discussion & 110 & 33.4 \\
\hline
\end{tabular}

\begin{tabular}{|l|c|c|}
\hline \multicolumn{3}{|c|}{ 8. Creative strategies generated and used working with press and } \\
technologies
\end{tabular}

9. Strategies recommended by teachers to work with press and technologies

\begin{tabular}{|l|l|l|}
\hline 1. Information analysis & 236 & 71.7 \\
\hline 2. Debates. Express their opinion & 235 & 71.4 \\
\hline 3. Look for vocabulary & 205 & 62.3 \\
\hline 4. Summarize & 205 & 62.3 \\
\hline 5. Edit & 205 & 62.3 \\
\hline
\end{tabular}

$13 / 20$

\begin{tabular}{|l|c|c|}
\hline 6. Television record & 183 & 55.6 \\
\hline 7. Comment & 177 & 53.8 \\
\hline 8. Radio programs record & 169 & 51.4 \\
\hline 9. Headline work & 169 & 51.4 \\
\hline 10. Do interviews & 160 & 48.6 \\
\hline 11. Investigate news & 120 & 36.5 \\
\hline 12. Visit newspapers & 36 & 10.9 \\
\hline
\end{tabular}

\begin{tabular}{|c|c|c|c|c|c|}
\hline \multicolumn{6}{|c|}{ 10. Teachers reasons to } \\
\hline \multicolumn{3}{|c|}{ START } & \multicolumn{3}{|c|}{ CONTINUE } \\
\hline $\begin{array}{l}\text { General } \\
\text { learning }\end{array}$ & 211 & 64.1 & Motivation & 172 & 52.3 \\
\hline $\begin{array}{l}\text { Favour the } \\
\text { relationship } \\
\text { with media and } \\
\text { tech-nologies }\end{array}$ & 198 & 60.2 & Boost feelings & 169 & 51.4 \\
\hline $\begin{array}{l}\text { Knowledge of } \\
\text { reality }\end{array}$ & 192 & 58.4 & $\begin{array}{l}\text { Generate } \\
\text { creativity }\end{array}$ & 151 & 45.9 \\
\hline Motivation & 189 & 57.4 & $\begin{array}{l}\text { Get familiar } \\
\text { with new } \\
\text { technologies }\end{array}$ & 145 & 44.1 \\
\hline $\begin{array}{l}\text { Didactic } \\
\text { possibilities }\end{array}$ & 178 & 54.1 & $\begin{array}{l}\text { Didactic } \\
\text { possibilities }\end{array}$ & 135 & 45.0 \\
\hline $\begin{array}{l}\text { Pedagogic } \\
\text { renewal }\end{array}$ & 129 & 39.2 & $\begin{array}{l}\text { New } \\
\text { knowledge }\end{array}$ & 131 & 39.8 \\
\hline \multirow[t]{2}{*}{$\begin{array}{l}\text { Develop } \\
\text { research }\end{array}$} & 98 & 29.8 & $\begin{array}{l}\text { Importance of } \\
\text { media }\end{array}$ & 112 & 34.0 \\
\hline & & & $\begin{array}{l}\text { Stimulates } \\
\text { reading }\end{array}$ & 92 & 280 \\
\hline
\end{tabular}

11. Objectives sought in working with new technologies

\begin{tabular}{|l|c|c|}
\hline Develop capacities & 202 & 61.4 \\
\hline Enlarge vocabulary & 200 & 60.8 \\
\hline Stimulate reading & 168 & 51.1 \\
\hline Create critical spirit & 147 & 44.7 \\
\hline Value media's role & 153 & 46.5 \\
\hline Make learning more dynamic & 135 & 41.0 \\
\hline
\end{tabular}

$14 / 20$ 
Acquire knowledge about current happenings

108

32.8

12. They remember pleasantly their student years when their teachers used media and technologies as examples.

\begin{tabular}{|l|c|c|}
\hline Read Newspapers & 196 & 59.6 \\
\hline Videos & 151 & 45.9 \\
\hline Magazines & 82 & 24.9 \\
\hline Cassettes & 81 & 24.6 \\
\hline Slides & 57 & 17.3 \\
\hline Wall charts & 56 & 17.0 \\
\hline
\end{tabular}

13. Those who learn with press and technologies learn more (closed

\begin{tabular}{|l|c|c|}
\multicolumn{3}{|c|}{ answers) } \\
\hline Reasoning & 262 & 79.6 \\
\hline Sociability & 254 & 77.2 \\
\hline Comprehension & 260 & 79.0 \\
\hline Contents & 226 & 68.7 \\
\hline Solidarity & 221 & 67.2 \\
\hline Abilities & 201 & 61.1 \\
\hline Logic & 170 & 51.7 \\
\hline Objectives & 152 & 46.2 \\
\hline
\end{tabular}

14. Those who study with press and technologies learn more (open answers...)

\begin{tabular}{|c|c|c|}
\hline Mental agility & 147 & 44.7 \\
\hline Open to ideas & 128 & 38.9 \\
\hline Behaviour & 126 & 38.3 \\
\hline Respect & 91 & 27.7 \\
\hline New knowledge & 73 & 22.2 \\
\hline Critical spirit & 73 & 22.2 \\
\hline Work techniques & 50 & 15.2 \\
\hline
\end{tabular}

15. Students and their families say about technologies

They are very satisfied

They provide motivation

\begin{tabular}{l|r}
233 & 70.8 \\
\hline
\end{tabular}

$15 / 20$

\begin{tabular}{|l|l|l|}
\hline Are entertaining & 50 & 18.2 \\
\hline
\end{tabular}

16. We think we have renewed the following thanks to press and technologies

\begin{tabular}{|l|c|l|}
\hline Teaching Methods & 261 & 79.3 \\
\hline Classroom atmosphere & 256 & 77.8 \\
\hline Relationship with students & 230 & 69.9 \\
\hline Curriculum contents & 153 & 46.5 \\
\hline Assessment & 56 & 17.0 \\
\hline
\end{tabular}

\begin{tabular}{|l|c|c|}
\hline \multicolumn{3}{|c|}{ 17. Teachers using press and new technologies got } \\
\hline Personal satisfaction & 217 & 66.0 \\
\hline Self learning & 184 & 55.9 \\
\hline New Motivations & 177 & 53.8 \\
\hline Curriculum connection & 152 & 46.2 \\
\hline Up-dating & 124 & 37.7 \\
\hline New pedagogic perspectives & 121 & 36.8 \\
\hline Group participation & 83 & 25.2 \\
\hline
\end{tabular}

\begin{tabular}{|l|c|c|c|c|l|}
\hline \multicolumn{7}{|c|}{ 18. Teachers who teach with video and their results } \\
\hline Never & 147 & 44.7 & 49 & 14.9 & Very poor \\
\hline Almost never & 107 & 32.5 & 132 & 40.1 & Poor \\
\hline Sometimes & 34 & 10.3 & 75 & 22.8 & Acceptable \\
\hline Almost always & 26 & 7.9 & 43 & 13.1 & Good \\
\hline Always & 3 & 0.9 & 9 & 2.7 & Very good \\
\hline No answer & 12 & 3.6 & 21 & 6.4 & No answer \\
\hline
\end{tabular}

\begin{tabular}{|l|c|c|c|c|l|}
\hline \multicolumn{6}{|c|}{ 19. Teachers who teach using computers and their results } \\
\hline Never & 72 & 21.9 & 42 & 12.8 & Very poor \\
\hline Almost never & 107 & 32.5 & 32 & 9.7 & Poor \\
\hline Sometimes & 92 & 28.0 & 134 & 40.7 & Acceptable \\
\hline Quite often & 35 & 10.6 & 77 & 23.4 & Good \\
\hline Always & 8 & 2.4 & 14 & 4.3 & Very good \\
\hline No answer & 15 & 4.6 & 30 & 9.1 & No answer \\
\hline
\end{tabular}

\section{Conclusions}

1. The studies carried out in the different levels clearly show the concerns 
of international and national institutions related with educations in order to innovate the educative systems. To achieve that, they trust the treatment of media in their different aspects of permanent and occasional resources and object of study themselves in all levels and subjects. To learn content is not the most important thing, but to be able to apply procedures and generate attitudes. Education must be permanent, for life, not only academic life but also professional and civic.

2. We are not looking for legal motivations teachers have to integrate press. Of course there are some, but we have tried to know the deep pedagogical reasons that have felt teachers to start this way of teaching. It is also important to notice the reasons that make them keep on working in innovations. Maybe these ones are repeated and differ in their value, and the new ones discovered represent a great richness discovered in this research.

3. Before integrating press into the teaching and learning processes, teachers think, get information. When teachers think about reasons they are transmitting the results obtained. In their reflective diagnosis they do not distinguish among goals, anticipated wishes and aims attained later. I considered convenient and even enriching to keep and note this approach down

4. When press is integrated into teaching is generated a new way of learning, a new way of understanding life and teaching, schools and classrooms. They appear new elements that lead to shape up a more enriching warm and human system. It is important to outstand how determinant new elements appear, such as classroom atmosphere, relationships with students, the teaching methods, etc. We can clearly notice that teachers are aware of how they suffer a positive transformation, although this means more work and dedication. They are really more satisfied and pleased with their work because of the good results obtained.

5. Research shows in the chapter of activities, that are understood not as questions to accomplish but as procedures such as press these are stimulated and even students create and think new ones without the intervention of the teacher. We outstand some of them because of their significance, as look up information in dictionaries, make comments, prepare small editions as class or thematic newspapers, wall charts, dossiers, investigate news, etc..

6. It is relevant that teachers before starting have some goals to accomplish, and after some time with the press they do not abandon the system or show mistrust or difficulties. They simply change the order of some objectives, procedures or strategies without altering the general planning. The trust in teaching and learning innovations is total.

7. We appreciate how motivation experienced by teachers and students is well considered there are in outstanding places the categories of contextualization, innovation, up dating of the curriculum, etc as very well valued reasons. Press shows experimentally how it provides with varied and plural resources that enrich all the formative process.

8. From this large convergent and reflective study with teachers who were asked to answer and value principles and categories innovated with the didactic and systematic use of media and new technologies. These promote significant activities where principles of individualization, collaboration, autonomy and diversity of students are developed. In this way, we can meet objectives, motivate much and conform a new class, subject and process organization.

\section{Sources and References}

Ballesta, J. (Coord.) (1995): Enseñar con los medios de comunicación. Barcelona. P.P.U.

Bartolomé Crespo, D. (Coord.) (1993): Prensa en las aulas I. Málaga. Edinford.

Bartolomé Crespo, D. (Coord.) (1996): Prensa en las aulas II. Madrid. CCS.

Boronat, J. (1995): Medios de comunicación y educación. Análisis de contenido de la prensa educativa. Palencia. Centro Asociado. UNED

Cabero, J. (1990): Análisis de medios de enseñanza. Sevilla. Alfar.

Cabero, J.; Martinez, Y. (Coordres.) (1995): Nuevos canales de Comunicación en la enseñanza. Madrid. Centro de Estudios. Ramón Areces.

Cabero, J (Coord.) (1996): Medios de comunicación, recursos y materiales para la mejora educativa. II. Sevilla. Kronos.

Castaño, C. (1994): Análisis y evaluación de las actitudes de los profesores hacia los medios de enseñanza. Bilbao. Universidad del País Vasco.

Gallego Arrufut, M. J. (Dir.) (1997): El profesorado y la televisión. Granada. Universidad de Granada. 
Garcia Valcarcel A. y otros (1994): «Tecnología educativa y nuevas tecnologías aplicadas a la educación». Enseñanza. N. 12. Salamanca.

Gervilla, A. (1992): Dinamizar y educar. Metodologías propuestas por la reforma. LOGSE. Madrid. Dykinson.

Lara Guerrero, J. (1992): Técnicas de estudio y rendimiento académico. Granada. Impredisur.

Marin Ibañez, R. (1986): Principios de la educación contemporánea. Madrid. Rialp.

Marin Ibañez, R. (1995): El sistema multimedia de la enseñanza a distancia. Madrid. UNED.

Mec (1989): Plan de Investigación Educativa y de Formación del Profesorado. Madrid. MEC.

Mec (1991): Las tecnologías de la Información en la Educación. Madrid. Mec.

Medina Rivilla, A. (1995): Enseñanza y Curriculum para la formación de personas adultas. Madrid. Cincel.

Medina A. Y Dominguez. C. (1991): El empleo del ordenador en la enseñanza. Madrid. Cincel.

Medina, A. (1990): La formación del profesorado ante las exigencias de la sociedad tecnológica. Madrid. Cincel.

Pablos Pons De, J. (1994): La tecnología educativa en España. Sevilla. Universidad de Sevilla.

Rodríguez Diéguez, J. L. y Saenz Barrio, O, (Coords) (1995): Tecnología educativa. Nuevas tecnologías aplicadas a la educación. Alcoy. Marfil.

Sevillano García, M. L. (coord.) (1995): Estrategias de EnseñanzaAprendizaje con Medios y Tecnologías. Madrid. Centro de Estudios Ramón Areces.

Sevillano García, M. L. Y Bartolomé Crespo (1997): Enseñar y aprender con la prensa. Madrid. CCS.

Sevillano García, M. L. (1996): Enseñanza - aprendizaje con medios de comunicación y nuevas tecnologías. Madrid .UNED.

Sevillano García, M. L. Y Bartolomé Crespo, D. (1991): Estrategias de enseñanza y aprendizaje en la Reforma. Madrid. UNED.

Sevillano García, M. L. et al. (coord.) (1993): Estrategias Metodológicas en la Formación del Profesorado. Madrid: UNED.

Sevillano García, M. L. (1997): Modificación de la inteligencia mediante la integración curricular de la prensa. Madrid. CCS.
Sevillano García, M. L. (1998): Estrategias de enseñanza - aprendizaje. Madrid. UNED.

Tulodziecki, G. (3. Auflage. 1997): Medien in Erziehung und Bildung. Klinhardt. Bad Heilbrunn.

Wittrock, M. C. (1989): La investigación de la Enseñanza I y II. Enfoques, teorías y métodos. Madrid: MEC y Paidós. 